\title{
Community Participation in the Development of Urban Farming in Yogyakarta City
}

\author{
Retno Wulandari ${ }^{1,2,{ }^{*}}$, Roso Witjaksono ${ }^{1}$, Ratih Inekewati $^{1}$ \\ ${ }^{1}$ Program of Extension and Development Communication, School of Post Graduate Studies, \\ Universitas Gadjah Mada, Yogyakarta, Indonesia \\ ${ }^{2}$ Department of Agribusiness, Agriculture Faculty, Universitas Muhammadiyah Yogyakarta, \\ Yogyakarta, Indonesia
}

\begin{abstract}
The optimal yard utilization would support the family's food independence a well-managed yard will provide benefits in improving family food self-sufficiency, nutrition, increasing family income, and making a beautiful, picturesque, and comfortable home environment. Efforts to build family food security in urban areas can be carried out through yard utilization on a narrow land. This study aims to determine the urban yard utilization and the members' participation in it. The research was conducted in Bausasran Subdistrict in Yogyakarta City, employing a descriptive analysis method with 40 samples of Women Farmer Groups' members. The research results revealed that community participation in urban yard utilization activities was classified as active. The community's active participation was indicated by the existence of "Kampung Sayur Bausasran", developed by establishing nursery gardens, creating group gardens, making vegetable aisles, cultivating medicinal plants, cultivating horticultural crops, and catfish farming. Vegetable villages can provide good results for community economic empowerment if managed optimally.
\end{abstract}

\section{Introduction}

Urban farming can be defined as activities of farming, processing, marketing, and distribution of food, forestry, and horticultural products carried out in and around urban areas [1]. The purpose of urban farming is to increase food availability and/or income, it may also as a relaxation and recreation activity for the doer[2]. The concept and implementation of urban farming in several countries have progressed and developed with numerous variants of farming and business models, as well as aspects of the mastery and the use of technology [3].

Urban farming is increasingly recognized as an essential contributor to urban food supply. Urban farming is well-developed in terms of the scale of production and economic impact [4]. There is widespread recognition of potential economic, environmental, and social outcomes, through private investment and consumer interest. [5] Unlike in rural areas, the agricultural system in urban areas has high complexity. It is caused by several

\footnotetext{
${ }^{*}$ Corresponding author : retno.wulandari@umy.ac.id
} 
factors, such as diverse variability factors, high dynamics, minimal organization, commitment to other jobs, and inexperienced community resources in the fields (agriculture, animal husbandry, fisheries, and product processing). Therefore, innovation systems and innovation recommendations commonly applied in rural areas cannot be fully implemented in urban areas. The availability of appropriate, effective, and efficient technical innovations is a prerequisite that must be met.

The urban land utilization is one action to support national food security[6]. In this case, the Special Region of Yogyakarta has actively developed Sustainable Food Houses (KRPL) implemented in its five regencies. Community activities in urban areas support yard utilization as an effort to develop agriculture and food independence in the area of Yogyakarta City. Yogyakarta is one of the cities with narrow land areas, yet the government took the initiative to allow communities to utilize their yards for planting.

Yogyakarta City has an area of $32.5 \mathrm{~km}^{2}$ land, having opportunity to be utilized and developed as intensive and modern land farming or farm space. Urban areas have relatively narrow land used for farming. Therefore, the government has taken the initiative to attract citizen to utilize their lands for farming. Urban farming offers alternative land utilization to integrate many land functions in densely populated areas [7].

Fulfilling basic needs at the household scale is essential in supporting food selfsufficiency[8]. The optimal yard utilization would support the family's food independence. The yard is a plot of land around the house which is easy to use to increase the fulfilment of micronutrients through family menu improvement. The yard is also referred to as a living granary, living stall, or living pharmacy. Various essential functions of the yard include a living stall, a living pharmacy, and a beauty function. A well-managed yard will provide benefits in improving family nutrition, increasing family income, and making a beautiful, picturesque, and comfortable home environment [9] .

The participation of human resources communities has great potential in the success of local development intiatives. The success of urban farming development is also inseparable from community participation through urban yard utilization. However, the problem in supporting the success of urban farming development is that people are less involved or even not involved or participating in urban farming development through narrow yard utilization. Community participation in yard utilization activities through garden aisles in Makassar City was high. These yards' management can be carried out in groups, thereby making it easy to plant, maintain, and harvest the yields [10].

However, several unorganized agricultural sites in urban areas remain exist. Meanwhile, farmers in urban areas require more diverse organizations than in rural areas, generally only oriented toward economic aspects (production, facilities, marketing, and capital). As in Bausasran Subdistrict, the community tries to utilize the narrow land to support urban farming development in Yogyakarta. Therefore, it is interesting to look at what efforts they have made in utilizing urban yard to develop urban farming and how they participated in it. This study aims to examine the urban yard utilization in Bausasran Subdistrict and community participation in supporting urban farming in Yogyakarta City.

\section{Research Method}

The research method of this study was a survey employing descriptive analysis. The study was conducted in Bausasran Subdistrict, Danurejan District, Yogyakarta City. The location was selected since there were four women farmer groups who have possessed vegetable gardens and utilized their yards. Since 2012 until now, at least three types of plants have been planted in the house yard using pots or polybags.

The research sample consisted of 40 people from Sekar Arum, Gemah Ripah, Amanah, and Bonjowi 4 Dasa women farmer groups. The sampling method was carried out using 
Proportionate Random Sampling. The total sample determination of 40 comprised eight samples from each of the Sekar Arum and Gemah Ripah Women farmer groups, six samples from each of Amanah and Bonjowi 4 Dasa Women farmer groups, and 12 samples of administrators from each group of women farmers.

Table 1. Sample of Member of Farmer Groups

\begin{tabular}{|l|c|c|c|c|c|c|}
\hline $\begin{array}{c}\text { Name of } \\
\text { Farmer Group }\end{array}$ & $\begin{array}{c}\text { Number of } \\
\text { Member }\end{array}$ & $\begin{array}{c}\text { Number of } \\
\text { Committee }\end{array}$ & $\begin{array}{c}\text { Total } \\
\text { Member }\end{array}$ & $\begin{array}{c}\text { Sample of } \\
\text { Member }\end{array}$ & $\begin{array}{c}\text { Sample of } \\
\text { Committee }\end{array}$ & $\begin{array}{c}\text { Total } \\
\text { Sample }\end{array}$ \\
\hline Sekar Arum & 22 & 3 & 25 & 8 & 3 & 11 \\
\hline Gemah Ripah & 22 & 3 & 25 & 8 & 3 & 11 \\
\hline Amanah & 17 & 3 & 20 & 6 & 3 & 9 \\
\hline Bonjowi 4 Dasa & 17 & 3 & 20 & 6 & 3 & 9 \\
\hline Total Member & $\mathbf{7 8}$ & $\mathbf{1 2}$ & $\mathbf{9 0}$ & $\mathbf{2 8}$ & $\mathbf{1 2}$ & $\mathbf{4 0}$ \\
\hline
\end{tabular}

The data were collected by interview or sample answer the surveys 40 farmers using interview guides. The questionnaire was divided into two parts: the first part contained the urban yard utilization, and the second part consisted of community participation in the urban yard utilization. The determination of community participation score employed the category of not involved, less involved, and involved. The total score of community participation was categorized as inactive, less active, and active participation.

Score analysis was employed to determine community participation in urban yard utilization activities. To disclose the category average total score of community participation, the interval width formula was used:

$$
\begin{aligned}
\text { Interval } & =\frac{\text { Maximum Score }- \text { Minimum Score }}{\text { Number of Score Categories }} \\
\text { Interval } & =\frac{3-1}{3} \\
& =0.66
\end{aligned}
$$

The categories for the average score for total community participation include:

$\begin{array}{ll}\text { Inactive } & : 1-1.66 \\ \text { Less Active } & : 1.67-2.33 \\ \text { Active } & : 2.34-3\end{array}$

\section{Results and Discussion}

Bausasran Subdistrict has five villages: Tegal Lempuyangan, Lempuyangan, Macanan, Ronodigdayan, and Bausasran, consisting of 12 RW (Citizens Association) and 49 RT (Neighborhood Association). Several subdistricts had a Farmer Group organization. In the village of Lempuyangan RW 05, there was a Farmer Group, but it was being pioneered, and the government had not approved it.

The Bausasran Subdistrict is located in Yogyakarta City, not far from the zero kilometer, the Malioboro tourist center, and Yogyakarta Lempuyangan Station. It has made the Bausasran Subdistrict area developed rapidly in economic sector, trade, industry, education, and population. Located in urban area, this area became the development center in the city. 


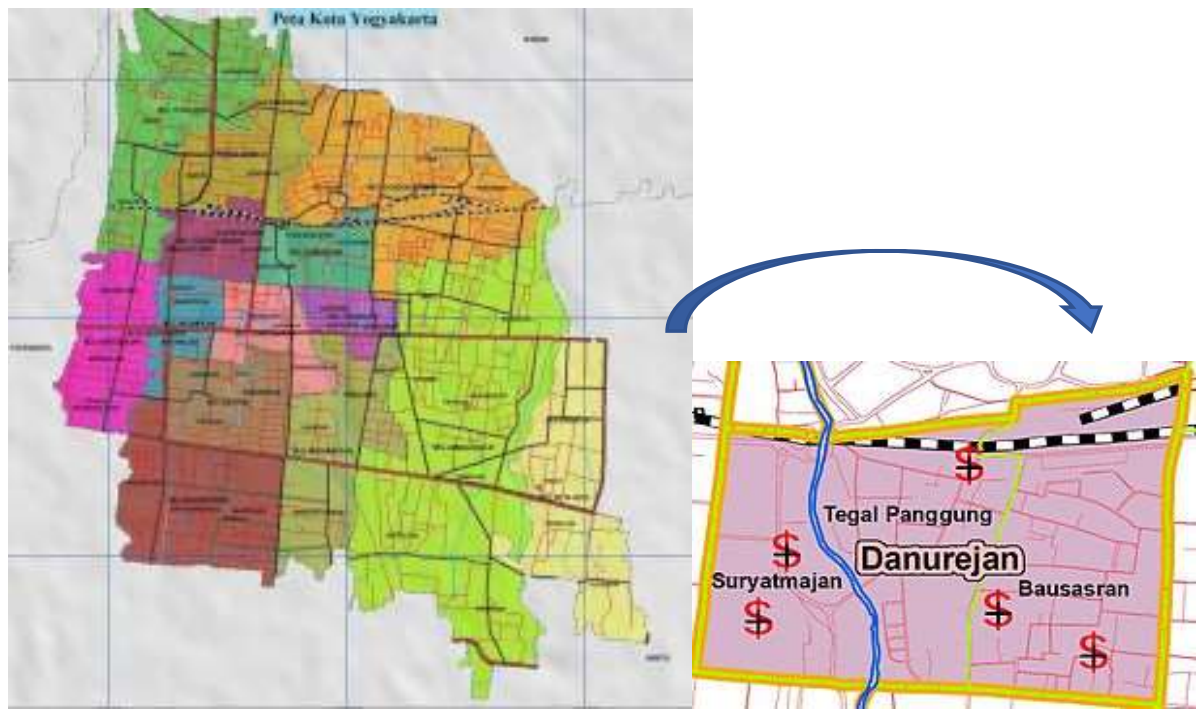

Fig.1. Map of Yogyakarta City and Bausasran Subdistrict

\subsection{Characteristic of Member of Women Farmer Group}

All samples in this study are women. Table 1 depicts that the most dominant member in each group, with a percentage of $42.86 \%$, was in the productive age category. In another Women Farmer Group, there was also a non-productive age, with a percentage of $21.43 \%$. According to the members, it was not an obstacle to participating in activities at the Women Farmer Group. Also, the reason for joining was to fill old age with productive activities. Besides, with the Women Farmer Group activities, they could consume food sources that they cultivated themselves. Another reason was also to motivate the younger members to participate in the Women Farmer Group activities.

In terms of members' education level, of the 40 members, all have received primary, secondary education, or several were undergraduate or university education. It indicated that members could understand to participate in all group activities.

The member's occupations were highly diverse. There were even members of the House of Representatives in Yogyakarta City. However, according to the members, it was not an excuse to work as a worker; the essential thing was to participate in the Women Farmer Group. As for some of the women farmers worked as traders or entrepreneurs, they argued that the Women Farmer Group's existence made an additional income for them because their products could also be sold in the Women Farmer Group in certain activities or exhibitions held by the government.

Moreover, most members joining each Women Farmer Group were relatively young, at a duration of 1-3 years with a percentage of $50 \%$. At a young age, members were excited to participate in activities. However, some members have long joined with a percentage of $7.14 \%$. 
Table 2. Characteristic of Member of Woman Farmers' Group

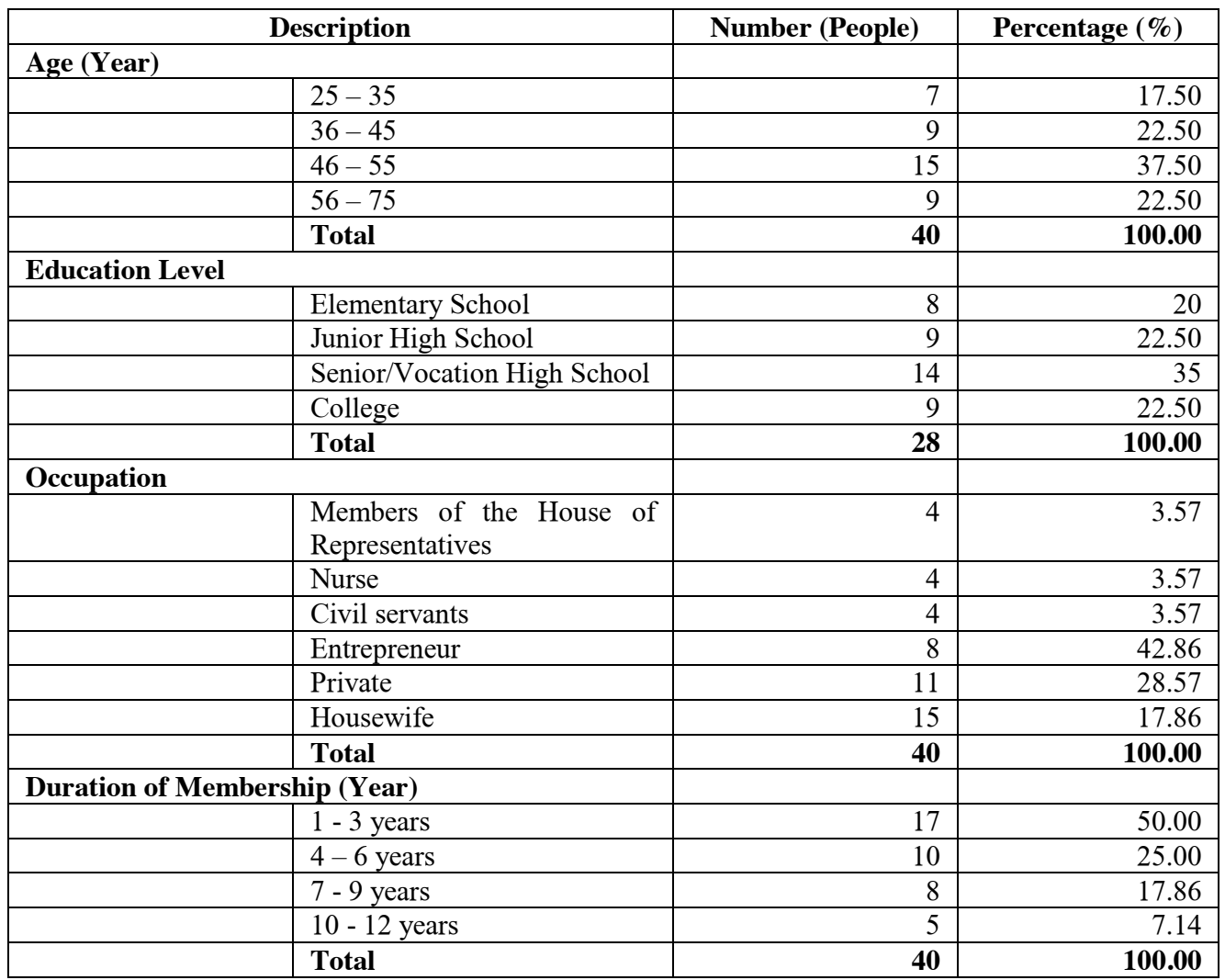

\subsection{Activities of Women of Farmer Group in Utilizing Urban Yards}

Women farmer groups activities in Bausasran Subdistrict were a series of activities attended by members and administrators. The activities of several women farmer groups in Bausasran Subdistrict currently running were urban yard utilization, where these activities optimized narrow land for planting various plants and fish farming. The cultivated plants were medicinal plants and horticultural plants, while the fish farming were catfish and ornamental fish.

The yardland utilization was pioneered by the Sekar Arum Women Farmer Group, founded in 2005, and has been categorized as Sustainable Food Home Area (KRPL). This KRPL was a government program and was funded by the government. The success of the Sekar Arum Women Farmer Group has motivated other similar groups to take advantage of empty land for planting and fish farming. This activity was not only carried out by members of the Women Farmer Group in Bausasran Subdistrict, but also by the surrounding community. The surrounding community of Bausasran usually utilized their yards for the planting of at least two types of plants, chili, and eggplant.

Several Women farmer groups in Bausasran Subdistrict have developed Bausasran Vegetable Kampong (Kampung Sayur Bausasran). It began with the use of empty land by planting various vegetables, ranging from lettuce, cabbage, mustard greens, cauliflower, chilies, eggplant, bitter melon, and tomatoes. The community utilizes urban yards by planting various kinds of vegetable, medicinal, and fruit plants to provide a green and beautiful atmosphere in the middle of a city, densely populated, and had narrow yards. 


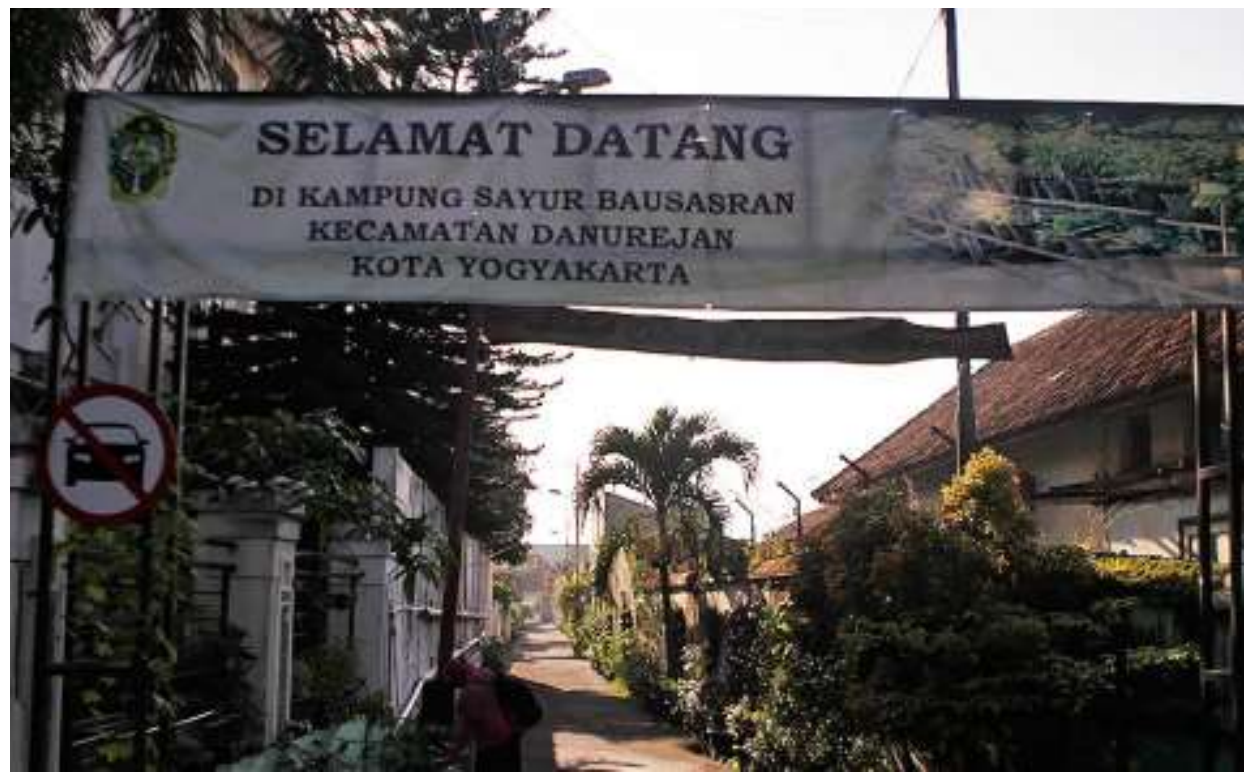

Fig. 2. Kampung Sayur Bausasran

In optimizing the use of land, several activities were carried out, including creating nursery gardens, setting up group gardens, and making vegetable aisles. The nursery was created in groups to make it easier to grow vegetable plant. Group garden was a typical garden planted with various vegetable and medicinal plants or herbs.
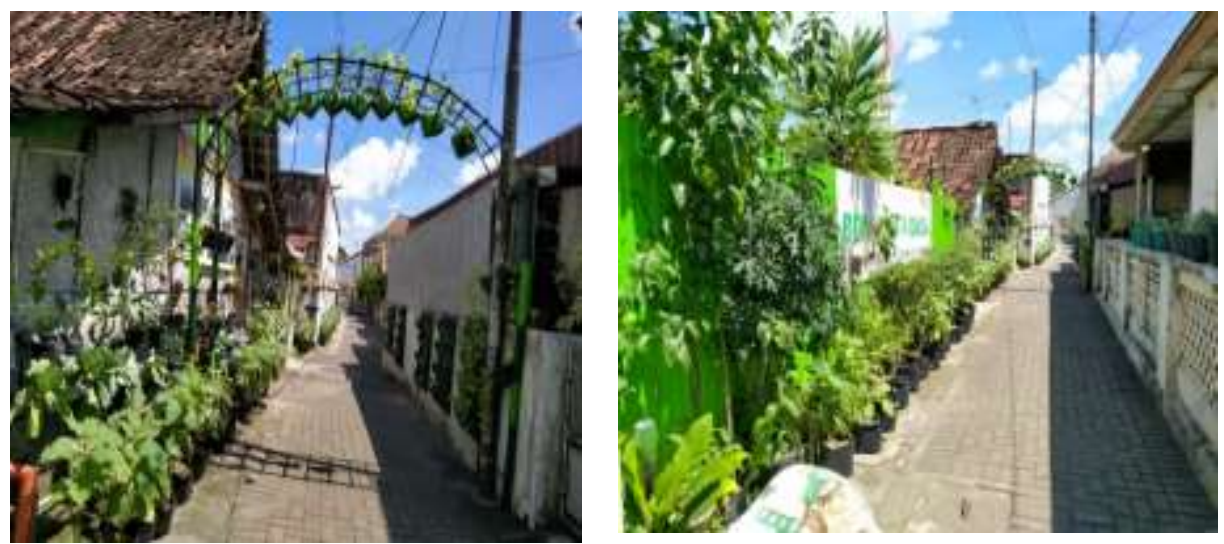

Fig. 3. Vegetable Aisles in Bausasran Subdistrict

One of the efforts to develop urban farming among the limited yards was by creating a vegetable aisle. This is in line with research conducted by Prasada \& Masyhuri (2019) that the use of agricultural land in urban areas can be done by increasing productivity agricultural land with efficient use of inputs and use of appropriate technology.[11] The vegetable aisle was a way of growing vegetables along an aisle or alley, where vegetable plants were planted either in pots or on the house's walls. There were also plants planted on racks made of bamboo and wood, placed along alleys and village roads. The community cultivated and maintained a variety of vegetable, medicinal, and fruit plants. This vegetable aisle was carried out using a landscape method (vegetable garden). This vegetable aisle was intended to green in urban areas and maintain family food security. Besides, the social 
benefits obtained from this effort were the creation of a united and harmonious society. The community could interact with fellow residents in their home environment. It could unite the community, with residents who frequently met and gathered to come up with creative ideas for urban farming development.

The types of plants grown in the vegetable aisles were vegetable crops, medicinal plants, and fruit plants. Vegetable plants grown included spinach, kale, chilies, mustard greens, tomatoes, eggplant, bitter melon, lettuce, broccoli, pokcoy, caisim, green lettuce, red lettuce, luffa, leek, basil, cosmos leaves, celery, cauliflower, carrots, sweet potatoes, regular cabbage, purple cabbage, and pumpkin. Medicinal plants planted comprised lemongrass, common ginger, red ginger, ginger emprit, bengle, binahong, aromatic ginger, turmeric, okra, aloe vera, galangal, white turmeric, cat's whiskers, lavender, lime, mint leaves, patikan cino, patikan kebo, grass jelly, red betel, pandan leaves, temu ireng, mangkokan leaves, duckbill, jowon chili, sambiloto, and striped grass. Meanwhile, fruit plants cultivated were strawberry, soursop, banana, mango, guava, papaya, srikaya, sapodilla, cucumber, and pomegranate.

\subsection{Participation of Farmer Group Members in Urban Farming Development Activities}

The group members' participation in urban farming development activities was one of the activities in Bausasran Subdistrict, where each Farmer Group has used empty land for cultivation activities, both plant cultivation and fish farming. Plant farming had three categorizations comprising ornamental plants, medicinal plants, and horticultural crops. Fish farming consisted of catfish and ornamental fish. Ornamental fish, commonly farmed, were gupi and koi. Apart from using their yards, the Farmers' Group also used agricultural produce in the vegetable garden to make processed products, such as catfish crackers, lettuce, and spinach chips. Other activities included training from government extension agents who held Field Schools in the form of training for each Farmer Group. Furthermore, there were also members meeting activities in each Farmer Group, both routine and nonroutine. The meetings were held at different times between Farmer Groups. The participation of group members in developing urban farming is presented in Table 2 below.

Table 3. Group members' participation in the Bausasran Subdistrict

\begin{tabular}{|c|l|c|c|}
\hline No & \multicolumn{1}{|c|}{ Type of activity } & Average Score & Category \\
\hline 1 & Ornamental Plant Cultivation & 2.20 & Less Active \\
\hline 2 & Medicinal Plant Cultivation & 2.50 & Active \\
\hline 3 & Horticultural Crop Cultivation & 2.54 & Active \\
\hline 4 & Catfish Farming & 1.97 & Less Active \\
\hline 5 & Ornamental Fish Cultivation & 1.57 & Inactive \\
\hline 6 & Marketing & 3.08 & Active \\
\hline 7 & Training & 2.36 & Active \\
\hline 8 & Routine Meetings & 2.56 & Active \\
\hline 9 & Non-Routine Meetings & 2.36 & Active \\
\hline 10 & Group Assistance & 2.48 & Active \\
\hline
\end{tabular}

1. Inactive : :1-1.66

2. Less Active : $1.67-2.33$

3. Active : $2.34-3$ 
The activity of plants and fish cultivation in Farmer Groups of Bausasran Subdistrict was utilizing empty yards to be used as cultivation sites. Three types of plants cultivated were ornamental, medicinal, and horticultural. Furthermore, catfish and ornamental fish were the types of fish cultivated.

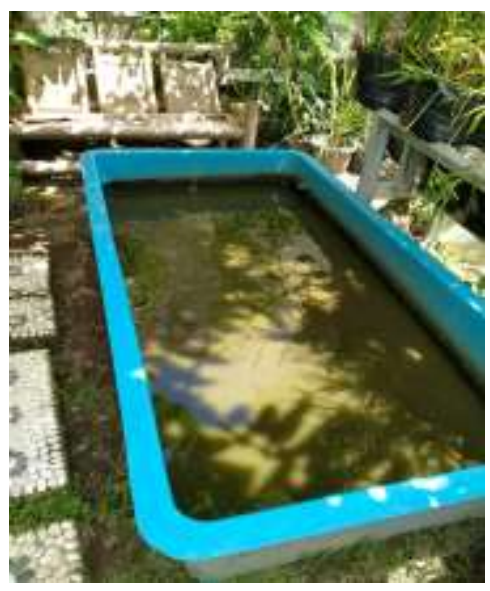

Fig. 4. Catfish Farming

Of the entire women farmer groups, Amanah Women Farmers just began the ornamental plant farming. Therefore, either the administrators or the members were not yet active in the activities. Sekar Arum Women Farmers did not carry out such activity because it was in a vacuum and was just about to begin rejuvenating plants gradually. Despite the incomplete members participating, both Gemah Ripah and Bonjowi 4 Dasa women farmer groups had run the activity for a while. The majority members of the farmers' group association in Bausasran Subdistrict had sufficient knowledge and experience regarding ornamental plant farming. However, a lack of participation in such activity resulted in a few members having limited knowledge and experience.

The Women Farmer Group members' participation regarding the medicinal plant cultivation in Table 3, starting from the planting media preparation, nurseries to the medicinal plant care, were included in the active category. It denoted that several members have participated in the medicinal plant cultivation. In each Farmer Group, the majority have participated in cultivating medicinal plants. It was because medicinal plants were needed in daily life, such as ginger and aromatic ginger, spices for a cooking mix for homemakers. Besides, medicinal plants are also natural and herbal medicines. Another reason was that this type of plant could be farmed in each house yard.

The medicinal plants cultivated by the Women Farmer Group in Bausasran Subdistrict consisted of lemongrass, common ginger, red ginger, emprit ginger, bengle, binahong, aromatic ginger, turmeric, okra, aloe vera, galangal, white turmeric, cat's whiskers, lavender, lime, mint leaves, patikan cino, patikan kebo, grass jelly, red betel, pandan leaves, temu ireng, mangkokan leaves, duckbill, jowon chili, sambiloto, and striped grass.

Members of Farmer Groups in Bausasran actively participated in horticultural crop farming activities, which included preparing planting media, nursery, plant care, harvesting, and post-harvest activities. Being a prima donna, it was not surprising that horticulture farming was the most active activity in each Farmer Group. Members took part in the horticultural plant cultivation because planting lots of vegetables and fruit motivated them to do so in their yards, even though their land was narrow. Also, with horticultural crops, they could meet their food needs. 
Horticultural crops planted by Women Farmer Group in Bausasran Subdistrict were vegetables and fruit plants. Vegetables included spinach, kale, chilies, mustard greens, tomatoes, eggplant, bitter melon, lettuce, broccoli, pakcoy, caisim, green lettuce, red lettuce, luffa, leek, basil, cosmos leaves, celery, cauliflower, carrots, sweet potatoes, regular cabbage, purple cabbage, pumpkin. Meanwhile, fruit plants covered strawberry, soursop, banana, mango, guava, papaya, sirkaya, sapodilla, cucumber, and pomegranate. This is in line with the research of [12] where farmers cultivate chili and tomato plants.

Members' participation in catfish farming activities ranging from pond preparation, feeding, pond cleaning, harvesting to post-harvest, belonged to the less active category. Several members have participated in this activity, but Gemah Ripah and Bonjowi 4 Dasa Women farmer groups left the pond preparation and cleaning activities to the men. Besides, catfish farming in Sekar Arum Women Farmer Group was carried out independently using a container, a large pot, and a small pond in front of the house. Whereas for the Amanah Women Farmer Group, pond cleaning and feeding activities were carried out by the AlAmna Mosque Manager due to the close location. As they did not require much energy, a few people carried out harvest and post-harvest activities. Catfish harvests were usually sold to members, processed into food products, and sometimes also distributed to Farmer Groups' members.

Members of Farmer Groups in Bausasran did not actively participate in ornamental fish farming activities covering pond preparation, feeding, and pond cleaning. It was because ornamental fish farming has not been maximized. So far, only two groups have conducted it, namely Gemah Ripah and Bonjowi 4 Dasa Women farmer groups. The Gemah Ripah Women Farmer Group just began the ornamental fish consisting of gupi and koi fish, given from the Department of Agriculture. Whereas for the Bonjowi 4 Dasa Women Farmer Group, gupi ornamental fish farming has been carried out, but only a few members were involved. Meanwhile, Sekar Arum Women Farmer Group ran chicken farming. In other words, this Farmer Group was not involved in the farming of ornamental fish. Due to the unavailability of ponds and fish seeds, Amanah Women Farmer Group has not carried out ornamental fish farming and wanted to focus on ornamental plant farming by adding more varieties of activities, as stated by the head of the Farmer Group.

Marketing was an activity existing in Women farmer groups in Bausasran Subdistrict. This marketing activity is vital for each Farmer Group because their products' marketing made the group known to the local community and government. Participation in marketing activities was classified as an active activity because several members played an active role in events or activities involving the products from each Women Farmer Group. Through marketing, each group would be known by people around, and those participating in events organized by the government. The marketing activity of each group was to use a stand to sell products. Moreover, the Amanah Women Farmer Group also opened an Amanah shop every day to sell its products, making it well known to the surrounding community.

Members' participation of women farmer groups in training activities and group meetings included training, routine meetings, non-routine meetings, and group assistance. The training was carried out by the government and followed by each group. This training activity was carried out by agricultural instructors assigned from the Department of Agriculture. The purpose was to assist group members in obtaining the latest knowledge and insights and in providing solutions for groups facing problems related to plant and fish farming. In the training activity, there was a processing training conducted every two months, including processing liquid compost using fermented banana stems, making mole fertilizer, and making vegetable pesticides. For catfish farming, processing activities focused on processing catfish's yield into shredded catfish, catfish crackers, and catfish sponge. Likewise, other products such as bokor lettuce, banana weevil chips, mocaf flour, and sweet potato brownies, were the agricultural processing products. 
The involvement of women farmer groups' members in training provided by the instructors belonged to the active category. It indicated that the members' participation in the training activity was high. The members participated in such activity to learn and add knowledge and insights regarding the yard utilization and activities during the practice. Members were more active in practical training activities than in training with theory because, with practice, they understood more and could immediately apply it in real life. There were two categories of participation. First, they were active if they have attended the training more than three times. Second, they were less active if they only participated in the activity three times. Most members participated in processing training activity more than four times, meaning that they were active.

Members' meeting was an activity in each Women Farmer Group, both routine and nonroutine. Routine meetings usually discussed problems in groups as well as problems regarding activities. Whereas non-routine meetings usually discussed both sudden and planned activities such as competitions, exhibitions, and bazaars. The members' involvement in routine meetings belonged to the active category, meaning that they have taken part in Farmer Groups' progress. Besides, the existence of routine meetings made members had to set aside time to participate in these activities. Routine meeting activities were not only discussing meetings' matters and problems but also community service in which each group has already had a schedule for community service together.

Table 3 shows that women farmer groups' members actively participated in non-routine meetings. However, the less active thing was their involvement in the meetings to discuss the exhibition because they thought the exhibition was rarely held. Besides, they also felt they had understood what to do in the exhibition, namely showing each member's products. In this case, only the group administrators who usually attended the meetings. However, it was different for non-routine meetings discussing competitions. The participation of members was quite active because they felt that competitions need more complicated preparation than the exhibitions, as in the case of administration, competitions' reports must be completed. Indeed, it triggered the members to participate actively and work together in the competition preparation.

Group assistance was carried out by instructors from the Department of Agriculture. The purpose of this assistance was to make each Farmer Group more active in carrying out activities. Moreover, they could consult about the problems regarding activities and plant cultivation and fish farming. Therefore, the group assistance made them increasingly active in participating in each group.

Concerning the group assistance, farmer members' participation was active category. In other words, they have been involved in efforts to advance women farmer groups. The majority in each women farmer group actively participated in assistance. They were active in participating in this activity because they wanted to obtain knowledge and broaden their horizons. Another reason was that members felt motivated by group assistance because it was to add activities.

\section{Conclusion}

The use of city yards in Bausasran District is carried out by making a Bausasran Vegetable Kampong (Kampung Sayur Bausasran), which aims to improved family nutrition and create a beautiful environment. In developing it, women's farmer groups have established nurseries, group gardens and vegetable aisles. Group members actively participate in medicinal plant cultivation, horticultural cultivation, marketing, training, member meetings, and group mentoring. However, members do not actively participate in ornamental fish cultivation. Moreover, members are less active in ornamental plant cultivation and catfish farming. 


\section{References}

1. J. Bailkey, Martin. Nasr, 2 (1999).

2. D. Huang and M. Drescher, Land Use Policy 43, 1 (2015).

3. D. Armstrong, Heal. Place 6, 319 (2000).

4. T. Krikser, A. Piorr, R. Berges, and I. Opitz, (2016).

5. F. Orsini, R. Kahane, R. Nono-Womdim, and G. Gianquinto, INRA 33, (2013).

6. A. Siegner, J. Sowerwine, and C. Acey, (n.d.).

7. S. T. Lovell, Sustainability 2, 2499 (2010).

8. I. Opitz, R. Berges, A. Piorr, and T. Krikser, Agric. Human Values 33, (n.d.).

9. M. Artmann and K. Sartison, (n.d.).

10. P. P. Anggun, M. Salim, and R. Rasyid, 1, 138 (2018).

11. I. Y. Prasada and M. Masyhuri, Agrar. J. Agribus. Rural Dev. Res. 5, (2019).

12. J. Mariyono, H. A. Dewi, P. B. Daroini, E. Latifah, A. Z. Zakariya, A. L. Hakim, and V. Afari-Sefa, Agrar. J. Agribus. Rural Dev. Res. 4, (2018). 